\title{
Biological evaluation of proteins: a new aspect
}

\author{
By A. E. BENDER AND B. H. DOELL \\ Research Department, Bovril Ltd, $\mathrm{I}_{4} 8$ Old Street, London, E.C. I
}

(Received 24 August 1956)

The growth method of comparing the nutritive value of proteins, namely the estimation of protein efficiency ratio (P.E.R.) has long been popular because of its simplicity despite its well-known drawbacks (Mitchell, I944).

Among the more serious disadvantages of this method are: $(a)$ no allowance is made for maintenance requirements of the test animal, $(b)$ the result varies with food intake, and $(c)$ the assumption that the gain in body-weight is indicative of the protein tissue laid down is not always valid.

A modification is described whereby a control group of animals fed on a protein-free diet is included in the experiment, and the difference between the weights of this group and the test group is used in the calculation instead of merely weight gain. This procedure allows for maintenance requirements and also permits the evaluation of poor proteins which do not promote growth (and of which, consequently, P.E.R. cannot be measured). The results obtained are independent of food intake. The third criticism mentioned above is shown to be of minor significance under our experimental conditions.

\section{EXPERIMENTAL}

Animals and diets. The rats and diets and amino-acid mixtures were as described previously (Bender, I956).

Body water. The whole carcasses, without evisceration or cleaning of the gut, were dried to constant weight in a hot air oven at $105^{\circ}$.

Fat. The dried carcasses were crushed in a mortar and extracted with diethyl ether in a Soxhlet apparatus for $24 \mathrm{~h}$. After evaporation of the solvent the extracted fat was dried at $105^{\circ}$.

Nitrogen. In the earlier experiments the whole defatted carcass was digested in a large Kjeldhal flask. In later experiments the defatted carcass was dissolved in $400 \mathrm{ml}$. $20 \%(\mathrm{w} / \mathrm{v}) \mathrm{HCl}$ in a Kilner jar by autoclaving for $\mathrm{I} \frac{1}{2} \mathrm{~h}$ at $\mathrm{rolb}$. pressure; the suspension was diluted to $500 \mathrm{ml}$. and portions were taken for nitrogen determinations. The digestion was catalysed with selenium.

Net protein utilization (N.P.U.). It was determined by the method of Bender \& Miller (1953) and Miller \& Bender (I955), the modified calculation of Bender \& Doell (1957) being used. The nitrogen content of the carcasses was calculated from the water content and often verified by direct estimation.

Net protein ratio (N.P.R.). Two groups, each of four animals, balanced as regards litter-mates and combined body-weight, were used in each test. One group was fed on 
the test protein at 10\% level, the other on a non-protein diet. At the end of the 7 - or Io-day feeding period the animals were weighed and the protein intake was measured.

N.P.R. is defined as (gain in weight of test-group +loss of weight of non-protein group) $\div$ protein intake. It thus measures the protein used for growth and the protein used for maintenance.

In practice seven test groups and one non-protein group were run simultaneously. The groups were from four litters each of eight rats.

Protein retention efficiency (P.R.E.). This term was given to the value obtained by converting N.P.R. into a percentage scale by use of an experimentally determined factor as described on p. I42.

\section{RESULTS}

Constancy of N.P.R.

The variation of P.E.R. with food intake (Bender, 1956) is to be expected from theoretical considerations (Table I). From similar calculations it follows that N.P.R. should be independent of food intake (Table I).

Table $\mathrm{I}$. Effect of food intake on protein efficiency ratio, net protein ratio and net protein utilization measured on rats

Theoretical calculation

Assumptions: $2 \mathrm{~g}$ protein required for maintenance; I $\mathrm{g}$ protein produces $5 \mathrm{~g}$ increase in body weight.

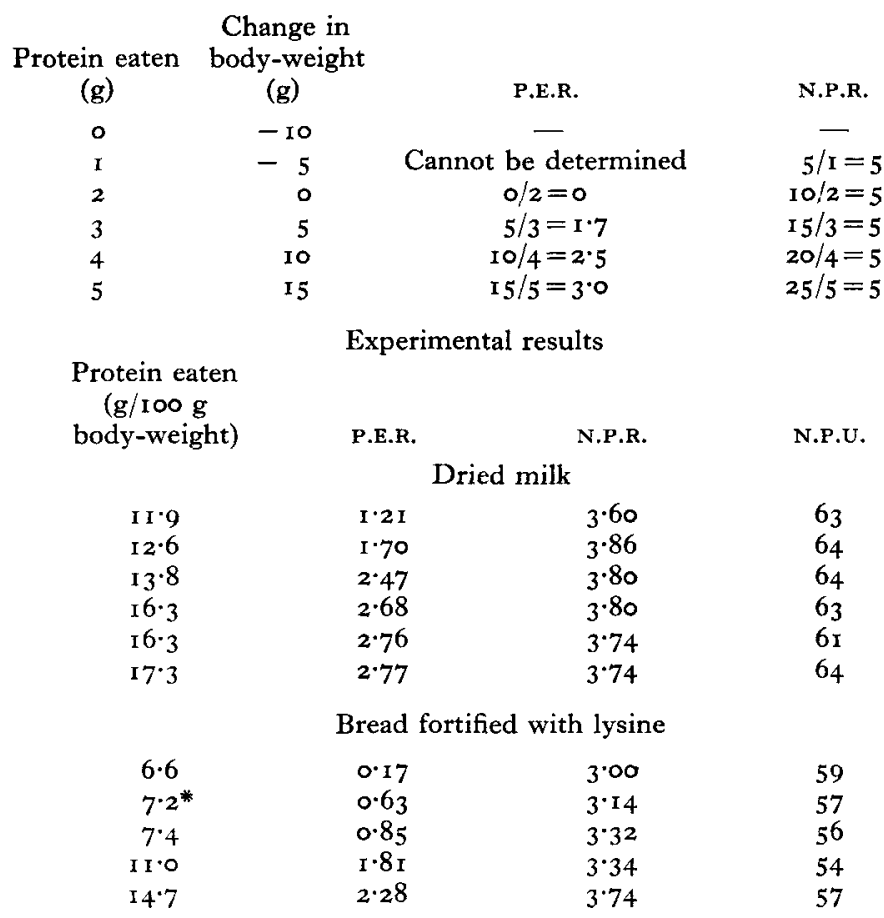

* 7-day experiment: protein intake multiplied by 10/7. All other figures were from I0-day experiments. 
The correctness of this theoretical treatment was borne out by results obtained with roller-dried skim milk tested on six occasions and with bread fortified with lysine tested on five occasions (Table $\mathrm{I}$ ), when ad lib. feeding resulted in varying food intakes. The P.E.R.'s varied with the food consumption, but the N.P.R.'s and N.P.U.'s were relatively constant.

\section{Relation between N.P.R. and N.P.U.}

The N.P.U.'s were measured on thirty-five proteins and mixtures of proteins, each value being replicated several times (Table 2). From the same data the P.E.R.'s and N.P.R.'s were calculated. Replicated P.E.R.'s showed wide variations (mean coefficient of variation $4 \mathrm{I} \cdot \mathrm{O}$ ) but N.P.R.'s were relatively constant (mean coefficient of variation $7 \cdot 4$ ). N.P.R. correlated with very high significance with N.P.U. (computed from the mean values): $y=3.3+15.5 x$ ( $y=$ N.P.U., $x=$ N.P.R.) $; r=0.986 ; P \ll 0.01$ (Fig. $\mathrm{r}$ ). The observed regression line begins very close to the origin and rises to a maximum of $6 \cdot 24$, corresponding to N.P.U. of 100 . This range compares with that for P.E.R. of $0-4 \cdot 4 \mathrm{I}$ (Bender, 1956).

\section{N.P.R. and P.R.E.}

Biological value (B.v.) and N.P.U. are expressed on a percentage scale, whereas P.E.R. is expressed as a value in the range of $0-4 \cdot 4$. Comparison between these two methods of measurement is therefore not immediately obvious. The suggested N.P.R. is also measured on a scale similar to that for P.E.R. and here again comparison with B.v. and N.P.U. is not immediately obvious. In view of the greater usefulness of a percentage scale it is suggested that N.P.R. measurements should be converted to such a scale. The conversion factor can be found from Fig. I, i.e. $100 / 6 \cdot 24=16$. It is suggested that this new value be termed protein retention efficiency.

\section{Body composition}

In view of the well-established fact that body composition varies with diet, age, length of feeding period, and many other factors, the finding that a weight method of measuring nutritive value (N.P.R.) correlated so well with $\mathrm{N}$ analysis (N.P.U.) was unexpected. Therefore a number of carcasses were analysed, after various diets had been fed, to determine the significance of the variation in body composition.

Groups of four rats were fed on various protein and non-protein diets for 7 or I4 days, killed when 44 days old, and the carcasses analysed for water, fat and protein (Table 3). The rats fed on $10 \%$ fish meal had very little more fat than the corresponding non-protein group, accordingly the percentage $\mathrm{N}$ and water in the two groups was the same. Despite significant differences in body composition between the egg-and the casein-fed rats and their non-protein groups, the differences between N.P.U. and P.R.E. were negligible. It is noteworthy that the rats fed on the $10 \%$ casein diet for 7 days contained $4 \%$ less fat than those fed on the same diet for $\mathrm{I} 4$ days (Tables 3 and 4 ).

To ascertain whether the fat was still low in older animals, groups of rats of different ages were fed on $10 \%$ casein diets or on non-protein diets for 14 days and their carcasses analysed (Table 4). The fat content of the rats of all the ages examined was low, although the fat of the protein-fed animals was approximately double that of the rats 


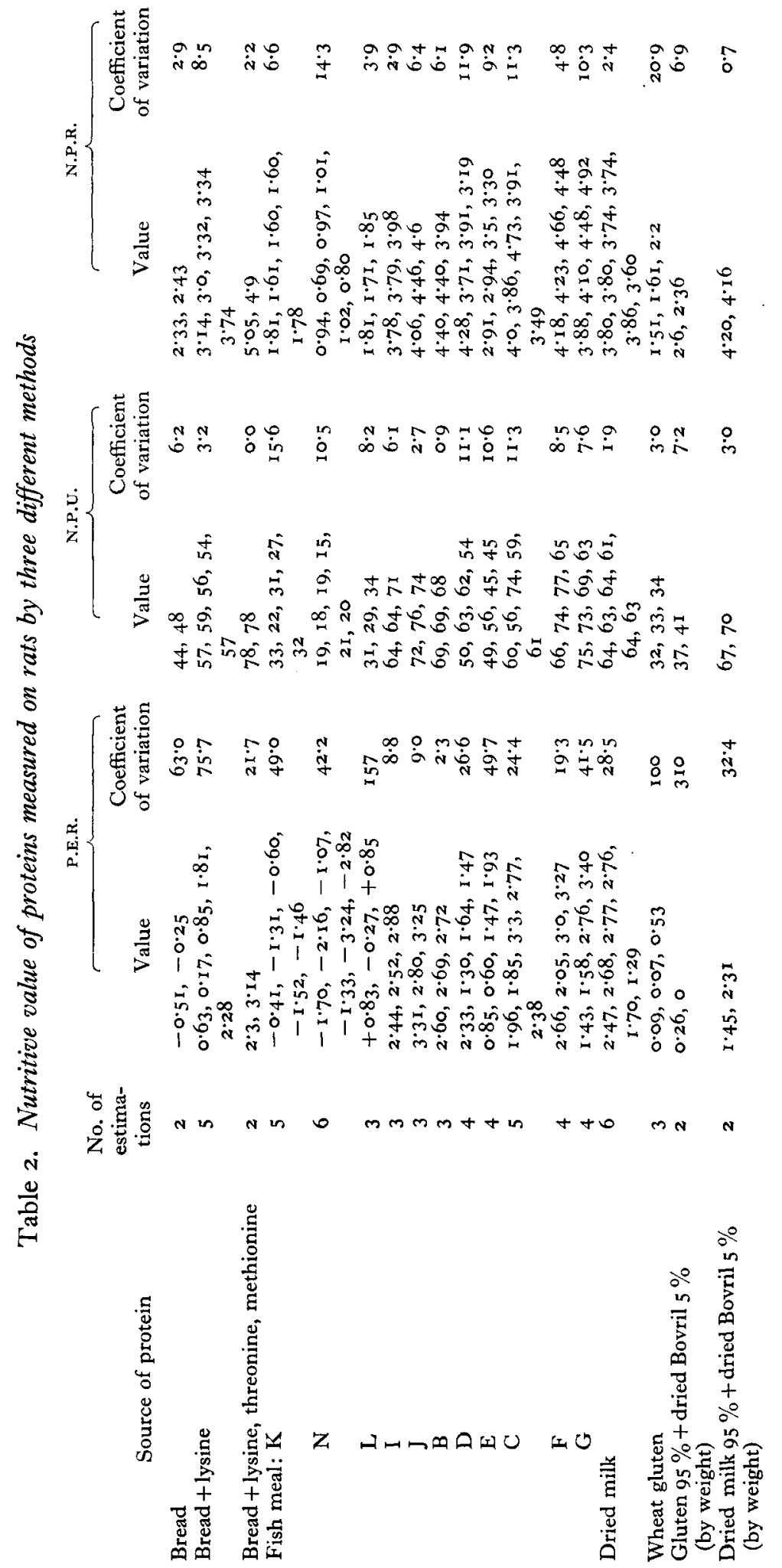




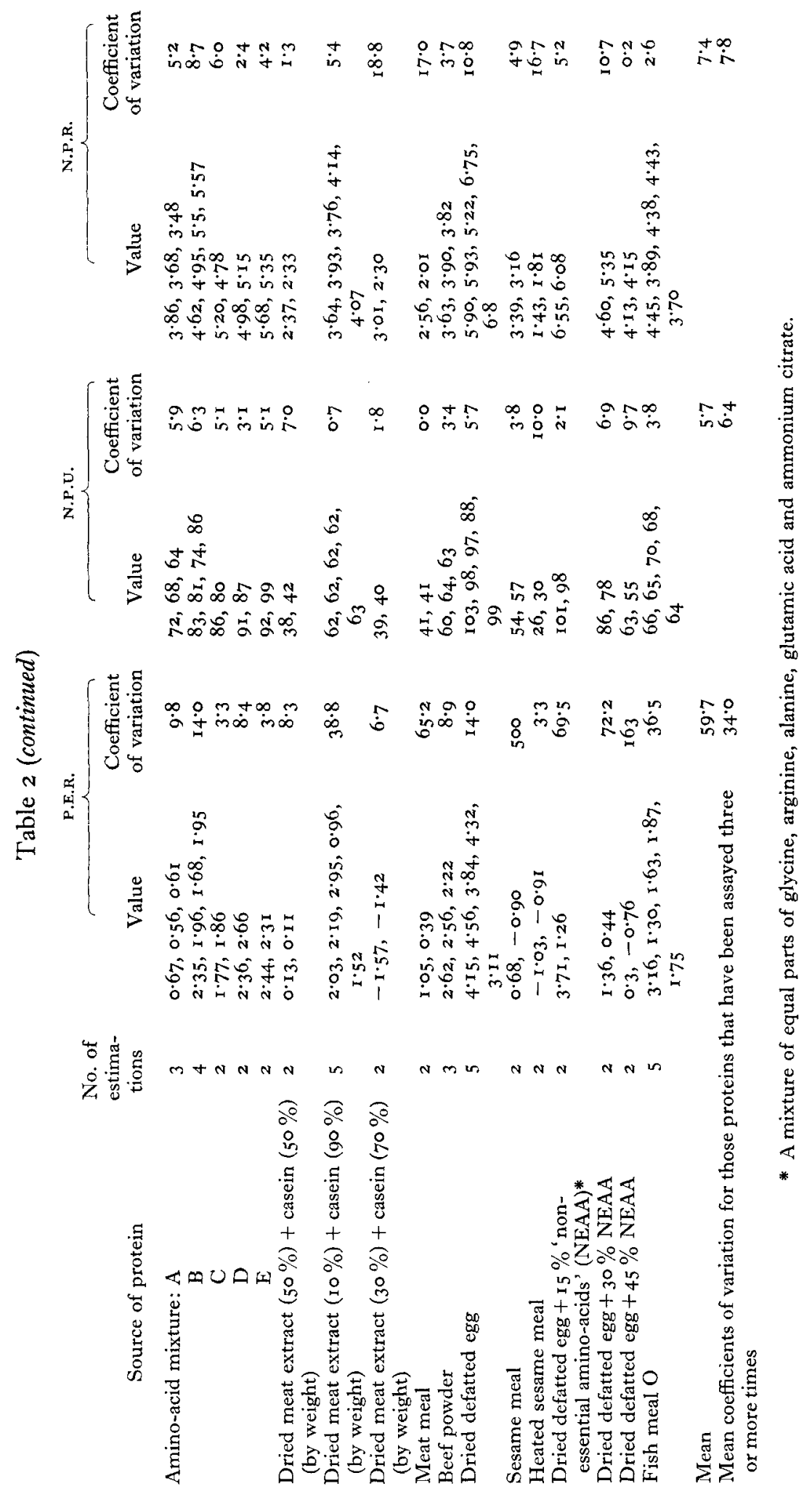


on the non-protein diet. Despite this difference the $\mathrm{N}$ contents, expressed as a percentage of the body-weight, were little different. There was consequently little difference between N.P.U. calculated from $\mathrm{N}: \mathrm{H}_{2} \mathrm{O}$ ratio and P.R.E. calculated from weight changes.

A total of 378 rats aged $27-32$ days were fed on various protein diets at a $10 \%$ protein level for Io days and their carcasses analysed for total $\mathrm{N}$. The mean $\mathrm{N}$ content was $2.68 \pm 0.13$ (S.D.) $\%$ of the body-weight. Ninety-three rats of similar age range were fed on the non-protein diet for Io days and their mean $\mathrm{N}$ content was $2 \cdot 81 \pm 0 \cdot 13$ (s.D.) $\%$ of the body-weight. These two values differ significantly $(P \ll 0 \cdot 01)$.

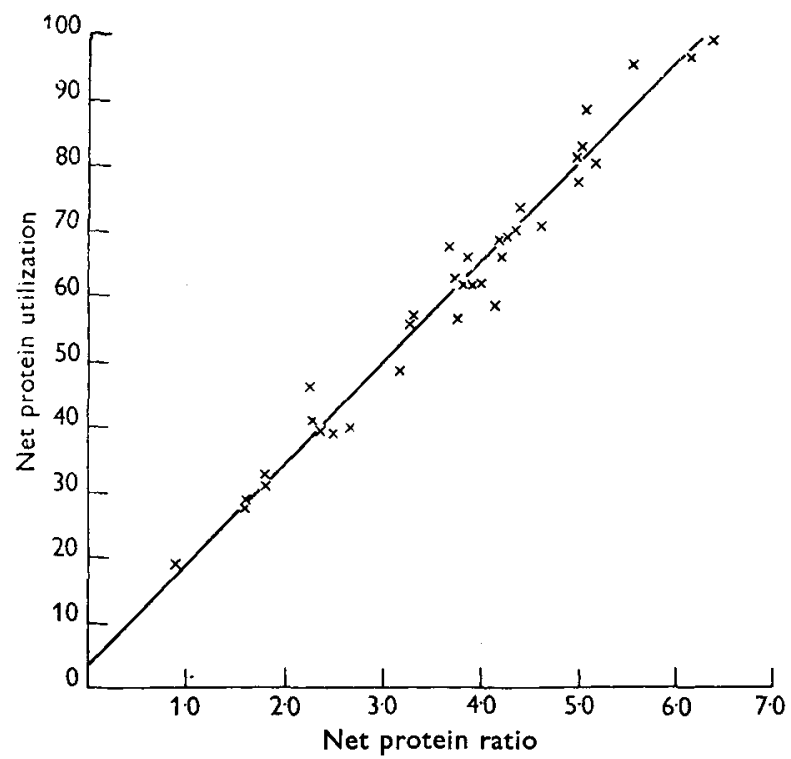

Fig. I. Correlation between net protein utilization $(y)$ and net protein ratio $(x)$.

$$
y=3.3+\mathrm{I} 5.5 x ; r=0.986 ; P \ll 0.0 \mathrm{I} \text {. }
$$

Table 3. Body composition of groups of four rats fed on various diets, and net protein utilization and protein retention efficiency calculated from it

\begin{tabular}{|c|c|c|c|c|c|c|c|c|c|}
\hline $\begin{array}{l}\text { Age } \\
\text { (days) }\end{array}$ & $\begin{array}{l}\text { Feed- } \\
\text { ing } \\
\text { period } \\
\text { (days) }\end{array}$ & Diet & $\begin{array}{c}\text { Water* } \\
(\%)\end{array}$ & $\begin{array}{c}\text { Fat* } \\
\text { ( } \% \text { wet weight })\end{array}$ & $\begin{array}{l}\text { Nitrogen* } \\
\text { (\% wet } \\
\text { weight) }\end{array}$ & $P+$ & $\begin{array}{c}\text { Ratio, } \\
\mathrm{N}: \mathrm{H}_{2} \mathrm{O}^{*} \\
(\%)\end{array}$ & N.P.U. & P.R.E. \\
\hline 44 & 14 & $\begin{array}{l}\text { 10 \% fish } \\
\text { meal } \\
\text { Non-protein }\end{array}$ & $\begin{array}{l}71 \cdot 2 \pm 0 \cdot 5 \\
71 \cdot 8 \pm 0 \cdot 6\end{array}$ & $\begin{array}{l}5.3 \pm 0.8 \\
4.5 \pm 0.4\end{array}$ & $\left.\begin{array}{l}2.74 \pm 0.06 \\
2.70 \pm 0.06\end{array}\right)$ & $\circ \cdot 3<P<0.4$ & $\left.\begin{array}{l}3.85 \pm 0.06 \\
3.77 \pm 0.09\end{array}\right\}$ & $29 \cdot 8$ & 29.5 \\
\hline 44 & I4 & $\begin{array}{l}\text { Io } \% \text { dried } \\
\text { defatted } \\
\text { eggt } \\
\text { Non-protein }\end{array}$ & $66 \cdot 3 \pm I \cdot 0$ & $10.7 \pm 0.7$ & $\left.\begin{array}{l}2.40 \pm 0.09 \\
2.85 \pm 0.07\end{array}\right\}$ & $<0.0 I$ & $\left.\begin{array}{l}3.61 \pm 0.14 \\
3.94 \pm 0.14\end{array}\right\}$ & $77 \cdot 2$ & 75.5 \\
\hline 44 & 7 & $\begin{array}{l}10 \% \text { casein } \\
\text { Non-protein }\end{array}$ & $\begin{array}{l}69 \cdot 8 \pm 0.9 \\
71 \cdot 9 \pm 0.5\end{array}$ & $\begin{array}{l}7.8 \pm 0.8 \\
4.0 \pm 0.5\end{array}$ & $\left.\begin{array}{l}2.73 \pm 0.07 \\
2.92 \pm 0.08\end{array}\right\}$ & $0.02<P<0.05$ & $\left.\begin{array}{l}3.96 \pm 0.09 \\
4.06 \pm 0.12\end{array}\right\}$ & $69 \cdot 3$ & $67 \cdot 3$ \\
\hline
\end{tabular}

* Value and standard deviation.

$\dagger P=$ probability that a mean difference at least as great as the observed mean difference between nitrogen contents would have arisen by random sampling from a homogeneous population.

$\ddagger$ This sample of dried defatted egg was apparently damaged since other preparations have given an N.P.U. of 95 . 
Table 4. Body composition of groups of four rats of different ages, and net protein utilization and protein efficiency ratio calculated from it

\begin{tabular}{|c|c|c|c|c|c|c|c|c|c|}
\hline $\begin{array}{c}\text { Age } \\
\text { (days) }\end{array}$ & $\begin{array}{l}\text { Feed- } \\
\text { ing } \\
\text { period } \\
\text { (days) }\end{array}$ & Diet & $\begin{array}{c}\text { Water* } \\
(\%)\end{array}$ & $\begin{array}{c}\text { Fat* } \\
\text { (\% wet } \\
\text { weight) }\end{array}$ & $\begin{array}{l}\text { Nitrogen* } \\
\text { (\% wet } \\
\text { weight) }\end{array}$ & $P+$ & $\begin{array}{l}\text { Ratio, } \\
\mathrm{N}: \mathrm{H}_{2} \mathrm{O}^{*} \\
(\%)\end{array}$ & N.P.U. & P.R.E. \\
\hline 44 & 14 & $\begin{array}{l}10 \% \text { casein } \\
\text { Non-protein }\end{array}$ & $\begin{array}{l}65 \cdot 4 \pm 0 \cdot 7 \\
70 \cdot 7 \pm 0 \cdot 7\end{array}$ & $\begin{array}{r}\text { II. } 8 \pm 0.8 \\
4.9 \pm 0.4\end{array}$ & $\begin{array}{l}2 \cdot 73 \pm 0.04 \\
2 \cdot 95 \pm 0.06\end{array}$ & $<0.0 I$ & $\left.\begin{array}{l}4^{\cdot 16} \pm 0.02 \\
4 \cdot 18 \pm 0.06\end{array}\right\}$ & $58 \cdot 5$ & $59 \cdot 8$ \\
\hline 64 & 14 & $\begin{array}{l}10 \% \text { casein } \\
\text { Non-protein }\end{array}$ & $\begin{array}{l}66 \cdot 0 \pm \times \cdot 1 \\
70 \cdot 1 \pm 0 \cdot 7\end{array}$ & $\begin{array}{r}\mathrm{II} \cdot 8 \pm \mathrm{I} \cdot 2 \\
4 \cdot 6 \pm 0.8\end{array}$ & $\left.\begin{array}{l}2.98 \pm 0.04 \\
3.14 \pm 0.21\end{array}\right\}$ & $0.1<P<0.2$ & $\left.\begin{array}{l}4.48 \pm 0.05 \\
4.48 \pm 0.31\end{array}\right\}$ & $6 I \cdot 2$ & $58 \cdot 6$ \\
\hline 84 & I 4 & $\begin{array}{l}\text { I0 \% casein } \\
\text { Non-protein }\end{array}$ & $\begin{array}{l}59 \cdot 7 \pm 3 \cdot 8 \\
67 \cdot 3 \pm 0 \cdot 7\end{array}$ & $\begin{array}{r}13.3 \pm 0.9 \\
6.9 \pm I .1\end{array}$ & $\begin{array}{l}2 \cdot 90 \pm 0.12 \\
3 \cdot 13 \pm 0.16\end{array}$ & $0.05<P<0.1$ & $\left.\begin{array}{l}4.85 \pm 0.33 \\
4.65 \pm 0.23\end{array}\right\}$ & 50.9 & 534 \\
\hline
\end{tabular}

\section{DISCUSSION}

\section{Relation between growth and nitrogen balance}

It has been usual in discussing methods of protein evaluation to separate growth methods from methods that involve the measurement of $\mathrm{N}$ balance (Fixsen, 1934-5; McCollum, Orent-Keiles \& Day, r939; Block \& Mitchell, 1946-7). In principle, this separation has no significance. Balance methods give the percentage of the protein retained in the body. Growth methods apparently give only the weight increase, but if it is converted to a protein increase relative to protein fed, and allowance is made for maintenance requirements as in the procedure described in this paper, then this value also becomes a measurement of the percentage of protein retained in the body.

To convert weight increase into protein increase it would be necessary to multiply it by the percentage of protein in the new tissue. The percentage of protein in the whole rat was 16.75 (determined on 382 animals fed on normal diets). The factor found empirically to convert N.P.R. to P.R.E. was I6. The difference is apparently due to the fact that the protein content of the new tissue is not quite the same as that of the whole carcass.

The new term, protein retention efficiency, is justified because, although it measures $N$ retention just as does N.P.U., the latter has the connotation of being derived from N-balance estimations, whereas P.R.E. is derived from weight changes.

\section{Constancy of body composition}

The modification of the P.E.R. method described here overcomes its major disadvantages, but is still apparently subject to the criticism of any growth method, namely, that the gain in body-weight does not necessarily bear a constant relation to the new protein tissue.

It has been shown by many workers that the composition of the body-weight gain varies with the type of diet (Mitchell \& Carman, 1926; Beadles, Quisenberry, Nakamura \& Mitchell, 1933; Kik, I938; Hamilton, I939). An examination of their findings, however, shows that these differences, which are mainly in the quantity of fat deposited, have very little effect on the percentage $\mathrm{N}$ of the total carcass. The variations in $\mathrm{N}$ are so small in relation to any biological measurement that they can be ignored. In Table 4 the fat content of the protein-fed rats is approximately double that of the non-protein 
group, yet the percentage of $\mathrm{N}$ in the bodies of the two groups differs by only about $8 \%$.

Barnes, Maack, Knight \& Burr (1945) found that rats fed on proteins at various levels for 42 days contained $17.8 \%$ protein $(2 \cdot 85 \% \mathrm{~N}) \pm \mathrm{II} \%$ (total range). This they considered to be within the normal range for biological experiments with small numbers of animals.

Beadles et al. (1933) showed that after feeding of equal quantities of two rations, although the two groups showed the same weight gains, these gains differed in composition. The feeding period was 50 days, compared with our Io-day period, but even then the $\mathrm{N}$ contents of the two groups were $2.7 \mathrm{I}$ and $2.53 \%$ respectively, differing by only $6.7 \%$.

Apart from this evidence that $\mathrm{N}$ is a fairly constant fraction of the total body in young rats, the fact that we show such good agreement between N.P.U. (derived from carcass N) and P.R.E. (derived from body-weight) demonstrates the insignificance of the variations in body composition in biological measurements of this kind.

\section{Application of P.R.E.}

Despite the drawbacks to protein evaluation by the estimation of P.E.R. (Mitchell, I944) the method is still widely used because of its simplicity. The measurement of P.R.E. retains all the simplicity of this method and overcomes most of the drawbacks. In addition, proteins that do not promote growth can be evaluated. Moreover, as the results are expressed on a percentage basis they are more readily interpreted.

\section{SUMMARY}

I. A modification of the commonly used growth method of assessing the nutritive value of proteins, the protein efficiency ratio, has been described and tentatively named protein retention efficiency (P.R.E.).

The procedure for obtaining this index consists of feeding a group of four rats on a diet containing 10\% of the test protein, and a group of litter-mates on a non-protein diet. After Io days feeding, the (algebraic) difference between the gains in weight of the two groups divided by the weight of protein eaten is defined to be the net protein ratio (N.P.R.). This ratio multiplied by $\mathbf{I} 6$, to correct it to a range of $0-100$, is called the protein retention efficiency (P.R.E.).

2. The P.R.E. was shown to correlate extremely highly with the net protein utilization determined by carcass analysis.

3. P.R.E. was shown to be independent of food intake. It includes the maintenance requirements of the test animal as well as the growth requirements.

4. Although the fat content of animals on different diets varied, this variation was small and had no marked effect on the percentage nitrogen of the body. It is concluded that body-weight is a reasonably accurate index of body protein in young growing rats.

We wish to thank Miss Sheila Haizelden and Mr Selby Humphreys for technical assistance. 


\title{
REFERENCES
}

Barnes, R. H., Maack, J. E., Knight, M. J. \& Burr, G. O. (1945). Cereal Chem. 22, 273.

Beadles, J. R., Quisenberry, J. H., Nakamura, F. I. \& Mitchell, H. H. (1933). F. agric. Res. 47, 947.

Bender, A. E. (1956). Brit. F. Nutr. Io, I35.

Bender, A. E. \& Doell, B. H. (1957). Brit. F. Nutr. 11, 138.

Bender, A. E. \& Miller, D. S. (1953). Biochem. F. 53, vii.

Block, R. J. \& Mitchell, H. H. (1946-7). Nutr. Abstr. Rev. 16, 249.

Fixsen, M. A. B. (1934-5). Nutr. Abstr. Rev. 4, 447.

Hamilton, T. S. (1939). F. Nutr. 17, 565.

Kik, M. C. (1938). Bull. Ark. agric. Exp. Sta. no. 352.

McCollum, E. V., Orent-Keiles, E. \& Day, H. G. (1939). The Newer Knowledge of Nutrition, 5 th ed. New York: The Macmillan Co.

Miller, D. S. \& Bender, A. E. (1955). Brit. J. Nutr. 9, 382.

Mitchell, H. H. (1944). Industr. Engng Chem. (Anal.), 16, 696.

Mitchell, H. H. \& Carman, G. G. (1926). Amer. F. Physiol. 76, 398.

\section{Effect of sex on the disappearance of carotene from the alimentary tracts of rats}

\author{
BY V. H. BOOTH* \\ Dunn Nutritional Laboratory, University of Cambridge and Medical Research Council \\ (Received I I September 1956-Revised 19 January 1957)
}

After carotene has been ingested by rats, about half of it can usually be recovered in the faeces. During the course of experiments done for other purposes it was observed that the proportion of the carotene that disappeared during its passage through the alimentary tract was greater in male than in female rats, irrespective of dose. The difference was small and, within any one experiment, not usually significant, but a significant difference emerged when the results of the several experiments were pooled. This paper presents the experimental evidence for that finding.

The terms 'absorption', 'digestion' and 'disappearance' have all been used for the difference between the carotene ingested and that excreted. The last is preferred because it involves no assumptions about intestinal destruction (Booth, I956).

\section{EXPERIMENTAL}

Separately caged piebald rats were given a basal diet devoid of vitamin A and carotenoids, but supplemented in certain experiments by a standard amount of vitamin $A$. Material containing a known amount of carotene was offered as a single dose. The dose given to each rat was weighed separately, and, within an experiment, the doses were closely similart: for instance, small dishes (artist's palettes) were weighed, canned

* Member of the scientific staff of the Agricultural Research Council.

+ The coefficient of variation of weight of one dose was usually $<4 \%$. 